University at Buffalo School of Law

Digital Commons @ University at Buffalo School of Law

\title{
Tribes as conservation easement holders: is a partial property interest better than none?
}

Jessica Owley

University of Miami School of Law, jowley@law.miami.edu

Follow this and additional works at: https://digitalcommons.law.buffalo.edu/book_sections

Part of the Environmental Law Commons, Indigenous, Indian, and Aboriginal Law Commons, and the Land Use Law Commons

\section{Recommended Citation}

Jessica Owley, Tribes as conservation easement holders: is a partial property interest better than none? in Tribes, Land, and the Environment 25 (Sarah Krakoff \& Ezra Rosser, eds., Routledge 2012)

This is an Accepted Manuscript of a book chapter published by Routledge in Tribes, Land, and the Environment on 04/28/2012, available online: < href="https://www.routledge.com/Tribes-Land-and-the-Environment/KrakoffRosser/p/book/9781409420620">https://www.routledge.com/Tribes-Land-and-the-Environment/Krakoff-Rosser/p/ book/9781409420620.

\section{IN COPYRIGHT}

This Book is brought to you for free and open access by the Faculty Scholarship at Digital Commons @ University at Buffalo School of Law. It has been accepted for inclusion in Contributions to Books by an authorized administrator of Digital Commons @ University at Buffalo School of Law. For more information, please contact lawscholar@buffalo.edu. 


\section{Tribes as Conservation Easement Holders: Is a Partial Property Interest Better than None?}

\section{Jessica Owley*}

The Klamath Tribes (composed of the Modoc, Klamath, and Yahooskin) are among the largest and wealthiest of American Indian nations. The current success of the Klamath is perhaps surprising in light of their unsettled history regarding their land. In the 1860s, the Tribes ceded over 23 million acres to the United States in exchange for a secure reservation and guaranteed hunting, fishing, and gathering rights along with other government-provided benefits. In 1954, the Klamath Tribes lost another 1.8 million acres in the termination process. ${ }^{1}$ Beyond the economic impacts of losing natural resources, termination was detrimental to the Tribes' spiritual connection with their ancestral lands, for which they held stewardship obligations.

While the Klamath have been successful in restoring their economy and political structure, they have struggled with regaining control of their traditional lands. The Tribes' traditional lands have been degraded and resources have been depleted. The Tribes have prioritized land reacquisition and ecosystem restoration to overcome the termination era legacies. The Klamath Tribes view return of their formerly held lands as "an essential element of their restoration as a people, and the reconstruction of their once vital economy." ${ }^{2}$ The Klamath Constitution references the Tribes' intent to reacquire all tribal land and resources ${ }^{3}$ and charges the tribal government with protecting the Tribes' wildlife and natural resources. ${ }^{4}$

An essential part of the Tribes' long-term plan to rebuild the community and restore the environment is reacquiring ceded and terminated lands from the federal government, which currently holds over 690,000 acres of Klamath land as U.S. Forest Service land. The Tribes are working with the federal

\footnotetext{
* Associate Professor, University at Buffalo (SUNY) Law School. Many thanks to Ezra Rosser and Sarah Krakoff for organizing the symposium that led to the book and for providing excellent editorial assistance and advice. I also benefited greatly from conservations with Beth Rose Middleton, whose recent book TRUST IN THE LAND: NEW DiRECTIONS IN TRIBAL CONSERVATION (University of Arizona Press 2011) is an invaluable resource for anyone interested in this area.

${ }^{1}$ Klamath Termination Act of 1954, P. L. No. 587, ch. 732, 68 Stat. 718 (1955) (codified at 25 U.S.C. 564). The termination policy did two things detrimental to the long-term protection of Klamath land. First, it removed many of the federal government's responsibilities to the Tribes that had earlier been established by treaty. Second, it took land out of tribal ownership and dispersed it to individual landowners. This land quickly moved out of tribal hands and beyond tribal control.

${ }^{2}$ The Klamath Tribes, The long Struggle Home: The Klamath Tribes; Fight to Restore Their Land, People and Economic SELF-SUFFICIENCY, http://www.klamathtribes.org/information/background/home.html (last visited June 15, 2011).

${ }^{3}$ The KLAmath TRIBES Const. art IV, $\S \mathrm{B}$.

${ }^{4}$ Id. § $\mathrm{H}$.
} 
government to resecure title to these lands. Return of these federally held lands to the Tribes will not reestablish all of the Klamath Tribes' former lands, however. Restoration of Klamath ancestral lands also includes acquiring land now in private hands. In their efforts to assert control over these lands in private hands, the Tribes are engaging in a new strategy. Instead of obtaining fee title to former Klamath lands, the Tribes entered into an agreement with private landowners to hold only a partial interest in the land.

Becky and Taylor Hyde, a ranching couple from Oregon, were determined to demonstrate that sensible management of property could restore even the most degraded habitats. To that end, they bought the Yainix Ranch (a severely degraded property) with the purpose of restoring it. From the beginning, they wanted to protect the property with a conservation easement. Conservation easements create perpetual restrictions on land use with the intent of yielding an environmental purpose. The potential enforcers, or holders, of conservation easements vary slightly by state law but are generally either nonprofit land conservation organizations or governmental entities.

After considering potential conservation easement holders, the Hydes decided to approach the Klamath Tribes. The Hydes felt that the Klamath Tribes had a genuine interest in preserving the natural resources on the land and had the long-term vision appropriate for conservation easement stewardship. The Yainix Ranch is on land once held by the Tribes, and the Klamath Tribes retain hunting, gathering, and fishing rights on the land. Thus, even though the Tribes had no experience with conservation easements, the landowners asked the Tribes to be part of their land restoration and protection endeavor.

While the Tribes hold the conservation easement, the U.S. Department of Agriculture funded the purchase and management of the conservation easement through the Natural Resources Conservation Service's (NRCS) Farm and Ranchland Protection Program. The state of Oregon also provided financial support through the Oregon Watershed Enhancement Board. Even with this structure, it took a few years of negotiating before the Klamath Tribes agreed to accept the conservation easement.

One of the deciding factors for the Tribes was likely the fact that the Yainix Ranch is on land that the Tribes held prior to the termination process in the 1950s. Protection of the Yainix Ranch is in keeping with the Tribes' stated interest in protecting ancestral lands. The decision to hold a conservation easement instead of seeking fee simple title to this land may be an acknowledgment that it will be difficult to obtain title to the over 1.8 million acres of ancestral lands now in the hands of the federal government and private landowners. Acquiring conservation easements over such land may be a way the Tribes can ensure appropriate management of the land until such a time as they can acquire fee simple title to it.

The story of the Klamath told here presents a potential model for other tribes seeking to obtain some control over lands outside of their jurisdiction. While the Klamath prefer obtaining fee simple title and establishing jurisdiction over ancestral lands, conservation easements offer them a way to control land use, protect tribal natural resources (on and off reservation), and develop amicable working relationships with nearby landowners.

This chapter explains how conservation easements work and then explores how and why tribal governments might choose to use them. While conservation easements may present a unique 
opportunity for extending tribal policies to private land, concerns regarding their structure and enforceability indicate that tribes should enter into these arrangements cautiously.

\section{Introduction}

Conservation easement use is growing rapidly, as is the number of organizations looking to the tool to meet land conservation needs. Until recently, tribes had not been involved in conservation easement transactions. Examples are now emerging of tribes taking part in conservation easements in multiple ways. Some tribes are deciding to hold conservation easements, either as a tribe or through tribal corporations and nonprofit organizations. Some tribes are choosing to encumber tribal land with conservation easements, giving nonprofit organizations the ability to enforce perpetual land-use restrictions on tribal land. Finally, some tribes are using their resources to support and promote conservation easements on other land, hoping the restrictions will benefit tribal land and resources.

This chapter examines the most common way tribes have become involved in conservation easement transactions - tribes as conservation easement holders. The chapter first defines conservation easements and provides general contours regarding their formation and use. Conservation easements are a creature of state law, and this discussion necessarily delves into that law before examining other legal foundations for tribes to hold conservation easements. The chapter next explores why tribes decide to hold conservation easements. This section looks at the choice to use conservation easements generally and then situates the decision in the evolution of property law in the United States both on and off tribal land. The availability of the conservation easement tool offers tribes a method for extending tribal environmental values and stewardship traditions beyond the borders of Indian land. However, conservation easements are a uniquely American form of property that emerge from Lockean roots and embrace a libertarian notion of property rights. In that light, tribal embrace of the tool may seem surprising as the both Lockean and libertarian notions of property have done harm to tribal sovereignty and may be at odds with traditional tribal practices. ${ }^{5}$

The chapter concludes by asking whether tribes should use conservation easements. Wrapped up in this question is an assessment of the conservation easement tool generally as a vehicle for long-term land protection. I have elsewhere ${ }^{6}$ cautioned local governments on their conservation easement use, and many of the same concerns apply to tribes deciding to hold conservation easements. The strength of the conservation easement tool is that it gives government entities the ability to extend their land conservation and environmental stewardship roles beyond their jurisdictional boundaries. Tribes may

\footnotetext{
${ }^{5}$ To describe "tribal notions of property" is a challenging (if not impossible) task. There is no single tribal notion of property or of environmental stewardship. To discuss tribes in general terms means gliding over the fact that we are talking about different nations, different people, and different traditions. Summarizing tribal notions of property in a book chapter necessarily involves painting tribal traditions with a broad brush and using simplistic examples. However, because there are some similar threads in the land-conservation practices of many tribes, the simple comparisons and summaries included herein still offer good fodder for considering the use of conservation easements by tribes in the United States.

${ }^{6}$ Jessica Owley, Use of Conservation Easements by Local Governments, in GREENING LoCAL GovernMment (Patricia Salkin \& Keith Hirokawa eds., forthcoming 2011).
} 
not have the power to regulate land use in nearby communities, but they can acquire conservation easements over such land and obtain similar results. Thus, despite some discordance due to the anticommunitarian sentiments at the heart of conservation easements, the conservation easement tool may provide tribes with an avenue for furthering tribal goals of conservation and intergenerational equity.

\section{HOW: The Mechanics of Tribes Holding of Conservation Easements}

\section{A. Conservation Easement Basics}

Conservation easements are nonpossessory interests in land with a conservation purpose. That is, they are servitudes restricting a landowner's ability to use her land in an otherwise permissible way with the goal that the restriction will yield an environmental benefit. Conservation easements usually restrict development. Under such an agreement, a landowner's ability to develop her land is restricted beyond what federal, state, and local laws already circumscribe.

Conservation easements are usually, but not necessarily, perpetual. Under classic property law terms, we conceptualize the landowner burdened by a conservation easement as the owner of the servient estate. In a change from the law of servitudes, however, the owner of the dominant estate is not necessarily a neighbor or even a landowner. State conservation easement statutes enable nonprofit organizations and government entities to be the owners (or holders) of the conservation easements regardless of their status as landowners. ${ }^{7}$ Holders of conservation easements have the right to enforce the agreements and ensure that landowners comply with the restrictions imposed. ${ }^{8}$

Conservation easement statutes outline the permissible purposes of conservation easements, set the rules regarding who may hold conservation easements, and define other terms and restrictions.

Although state laws vary in these requirements, there are many similarities among them. ${ }^{9}$ Over twenty states have adopted some form of the Uniform Conservation Easement Act (UCEA) promulgated by the National Conference of Commissioners on Uniform State Laws in $1981 .^{10}$

As their name indicates, conservation easements must have a conservation purpose. The UCEA sets forth the following as a list of acceptable purposes:

retaining or protecting natural, scenic, or open-space values of real property, assuring its availability for agricultural, forest, recreational, or open-space use,

\footnotetext{
${ }^{7}$ See, e.g., Uniform Conservation EASEMENT Act § 1(2)(i) [hereinafter UCEA]; Cal. Civ. Code $\S 815.2$; N.Y. EnVTL. CONSERV. LAW § 49-0303(2).

${ }^{8}$ In some cases, holders also have affirmative obligations usually relating to maintenance of vegetation, signs, or trails.

${ }^{9}$ Powell on Real Property contains a short overview of the various state laws, explaining broadly the differences among the state conservation easement statutes. 4-34A POWELL ON REAL PROPERTY § 34A.03 (Michael Allen Wolf ed. 2010).

${ }^{10}$ Available at http://www.law.upenn.edu/bll/archives/ulc/ucea/2007_final.htm. Although the act itself has not been amended, the Executive Committee amended the prefatory notes and comments in 2007 to update the discussion of charitable trusts.
} 
protecting natural resources, maintaining or enhancing air or water quality, or preserving the historical, architectural, archaeological, or cultural aspects of real property. ${ }^{11}$

Conservation easements are governed by state conservation easement statutes-not common law. However, in most states, they are still tied to common law rules regarding servitudes. Most conservation easement statutes indicate that conservation easements should follow the same general rules as traditional easements when it comes to issues like recordation, amendment, and termination. ${ }^{12}$ Thus, when examining conservation easements, one must consider the state conservation easement statute as well as state statutory and common law of easements. Additionally, conservation easements often create conservation trusts and the agreements are akin to contracts. To fully understand and evaluate the validity and worth of a conservation easement, one must be well versed in property, contract, and trust law. Where tribes are part of the arrangements, we add federal Indian law to the mix, specifically questions involving jurisdiction and sovereignty.

One way that tribes become involved in conservation easements is by deciding to hold conservation easements on nontribal land. That is, tribes negotiate restrictions with landowners. In exchange for agreeing to the land restrictions, the landowner generally obtains (1) federal income tax deductions, (2) money, or (3) a land-use permit. ${ }^{13}$

\section{B. State Conservation Easement Statutes}

State conservation easement statutes define permissible holders of conservation easements. Most statutes define two types of holders: nonprofit organizations with land-conservation missions (or land trusts) and governmental entities. Two states add tribes to this list. No state explicitly prohibits tribes. Thus, conservation easement statutes fall into one of three groups: (1) those that specifically allow tribes to hold conservation easement, (2) those that impliedly allow tribes to hold conservation easements, and (3) those that impliedly prohibit tribes from holding conservation easements.

\section{Specifically Allowed}

Two states explicitly recognize the rights of tribal governments to hold conservation easements: California and Oregon. California's main conservation easement statute, the California Conservation Easement Act (or CalCEA) was passed in 1979. The statute was amended in 2004, adding federally recognized California Native American tribes to the list of permissible holders. ${ }^{14}$ The statute explains that a "federally recognized California Native American tribe or [] nonfederally recognized California Native American tribe that is on the contact list maintained by the Native American Heritage

\footnotetext{
${ }^{11}$ UCEA § 1(1).

${ }^{12}$ See, e.g., UCEA § 2(a). There is a fair amount of debate within the land trust community as to what this actually means. Some scholars feel that charitable trust doctrines apply to conservation easements in a way that trumps this phrase. When trying to determining the rules regarding amendment, merger, and termination be sure to investigate the property, contract, and trust law implications in your state.

${ }^{13}$ I have only seen examples of tribes holding purchased or donated conservation easements, but they could also hold exacted conservation easements. Additionally, some conservation easements are the result of court settlements and eminent domain proceedings. Although there do not appear to be any tribal holders of such conservation easements, it is an arrangement that could develop.

${ }^{14} \S 815.3(c)$, added by Stats 2004, c. 905 (S.B.18), § 2.
} 
Commission to protect a California Native American prehistoric archaeological, cultural, spiritual, or ceremonial place" can hold a conservation easement as long as that conservation easement is "voluntarily conveyed." 15

Passed in 1983, Oregon's conservation easement act adopts some of the UCEA's language, but has unique requirements regarding permissible holders:

(3) “Holder" means:

(a) The state, any county, metropolitan service district, soil and water conservation district, city or park and recreation district or a county service district established under ORS 451.410 to 451.610 to construct, maintain and operate service facilities in Washington or Clackamas Counties for the purposes specified in ORS 451.010 (1)(a) and (b) and in Washington County for the purpose specified in ORS 451.010 (5) acting alone or in cooperation with any federal or state agency, public corporation or political subdivision;

(b) [a land trust]; or

(c) An Indian tribe as defined in ORS $97.740 .{ }^{16}$

Subsection (c) was added to the act in 2001.

Both California and Oregon acknowledge the validity of conservation easements held by tribes and expand the definition of tribes somewhat beyond federally recognized tribes. This explicit statutory inclusion of tribes as holders means that a conservation easement will not be held invalid solely because a tribe is serving as the holder. Such language may increase the faith landowners or funders will have in tribes as holders. Provisions such as these that bolster confidence in the enforceability of the agreements may enhance their use.

\section{Impliedly Allowed}

Many states model their statutes after the Uniform Conservation Easement Act. Commissioners at the National Conference of Commissioners on Uniform State Laws (NCCUSL) wrote the model act in 1981, and it has been adopted in whole or part by at least twenty-one states. ${ }^{17}$ The act sets forth two categories of permissible holders:

\footnotetext{
${ }^{15}$ CAL. CIV. CODE $\S 815.3(\mathrm{c})$. The meaning of this phrase is unclear. This requirement also applies to state and local government holders but not to land trusts. Arguably, it prevents tribes from holding any conservation easement created by condemnation or judicial decree (as with natural resource damages). One could read it to also prohibit tribes from holding exacted conservation easements. No California court has interpreted this phrase. See Jessica Owley, Enforceability of Exacted Conservation Easements (work in progress).

${ }^{16}$ OR. REV. STAT. § 271.715(3). Interestingly, ORS § 97.740 is a section of state law regarding Indian graves, but section (4) of that law defines Indian tribe as "any tribe of Indians recognized by the Secretary of the Interior or listed in the Klamath Termination Act, 25 U.S.C. 3564 et seq., or listed in the Western Oregon Indian Termination Act, 25 U.S.C. 3691 et seq., if the traditional cultural area of the tribe includes Oregon lands."

${ }^{17}$ UnIFORM LAW COMMISSION, LEGISLATIVE FACT SHEET-CONSERVATION EASEMENT ACT, at http://www.nccusl.org/LegislativeFactSheet.aspx?title=Conservation\%20Easement\%20Act (last visited June 15, 2011).
} 
(i) a governmental body empowered to hold an interest in real property under the laws of this State or the United States; or

(ii) charitable corporation, charitable association, or charitable trust, the purposes or powers of which include retaining or protecting the natural, scenic, or open-space values of real property, assuring the availability of real property for agricultural, forest, recreational, or open-space use, protecting natural resources, maintaining or enhancing air or water quality, or preserving the historical, architectural, archaeological, or cultural aspects of real property. ${ }^{18}$

This definition of governmental holder is much broader than seen in either the California or Oregon statutes. Although nothing in the legislative history indicates the commissioners drafting the UCEA considered the possibility that tribes might choose to hold conservation easements, tribes appear to fit under the definition of governmental holder. To confirm this in each state, we must determine whether the state recognizes a tribe as a "governmental body" 19 and then examine whether a tribe is "empowered to hold an interest in real property under the laws of th[e] state or the United States." 20

Other state statutes use similar language. For example, in Massachusetts ${ }^{21}$ and Montana ${ }^{22}$ conservation easements can be held "by any governmental body" and in Colorado ${ }^{23}$ and Utah, ${ }^{24}$ it is a "governmental entity." In Hawaii, it is even broader as conservation easements can be held by "any public body." ${ }^{25}$ It is not clear that conservation easements held by tribes would be valid under these various laws. Some

${ }_{18}^{18}$ UCEA § 1(2). Seventeen states use the same definition for governmental holders: Alabama, Alaska, Arizona, Delaware, Georgia, Idaho, Indiana, Kansas, Kentucky, Maine, Minnesota, Mississippi, Oklahoma, South Carolina, South Dakota, Texas, West Virginia. Louisiana's definition differs only by requiring the interest to be in "immovable property." LA. REV. STAT. ANN. §9-12721(a). Nevada's statute is slightly simpler, explaining that it is a "governmental body empowered to hold an interest in real property," without mention of state or federal law. NEV. REV. STAT. $\S 111.390(2)(a)$. Pennsylvania refers to the commonwealth instead of the state. 32 PA. CONS. STAT. § 5051(1). Wisconsin changes "a governmental body" to "any governmental body." WIS. STAT. § 700.4(1)(b)(1). See also MASS GEN. LAWS. Ch $184 \S 32$ (a conservation easement "may be acquired by any governmental body ... in the same manner as it may acquire other interests in land").

${ }^{19}$ For example, tribes and tribal governments do not appear to meet the definition of "governmental body" under Wisconsin law, which defines governmental body as a "state or local agency, board, commission, committee, council, department or public body corporate and politic created by constitution, statute, ordinance, rule or order[.]" WIS. STAT. § 19.82(1). It makes sense for state definitions of governmental bodies to omit tribes as generally state laws regarding governmental entities will not apply to tribes. It is unclear whether a tribe could successfully argue that it qualifies as a governmental body for conservation easement laws but need not meet other legal requirements for governmental bodies (like open meeting laws).

${ }^{20}$ UCEA § 1(2). The Klamath Tribes' constitution recognizes a tribal right to hold interest in real property. However, based on the language of the UCEA it must be state or federal law that recognizes the right. Tribally owned land falls into three categories: trust lands, restricted fee lands, and nonrestricted fee lands. The trust lands are owned by the federal government and held in trust for the tribes. For fee lands, the tribe holds the title. Sometimes the land is encumbered by legal restrictions regarding alienation or encumbrances. Nonrestricted fee lands enable a tribe to obtain legal title under specific statutory authority. Whether states would require an additional federal law recognizing a tribe's ability to hold conservation easements specifically is uncertain.

${ }^{21}$ MASS. GEN LAWS CH $183 \S 32$.

${ }^{22}$ Mont. COdE ANN §76-6-201(1).

${ }^{23}$ Colo. Rev. Stat. $\S 38-30.5-104(2)$.

${ }^{24}$ UTAH CODE ANN. §55-18-3.

${ }^{25}$ HAW. ReV. STAT. § 198-3. 
states require governmental holders to have a conservation purpose. ${ }^{26}$ Tribes may struggle with this requirement, as it is hard to define the purposes of a tribe in the same narrow confines as we see in the purpose sections of conservation easements.

\section{Impliedly Prohibited}

While many state statutes contain broad language that could encompass tribes, a few states have language that clearly leaves tribes off the list of permissible holders. Where a state law specifically names qualifying governmental entities but does not include tribes on that list, the statute impliedly prohibits tribal holders. For example, New Mexico appears to prohibit tribal holdings because the law prohibits all governmental ownership of conservation easements. ${ }^{27}$ While no other statute contains such a broad prohibition-explicitly prohibiting tribal holders-some of the implied language is hard to read in any other way.

For example, in lowa, the defined category of governmental holder is a specific list of entities: "The department of natural resources, soil and water conservation districts ..., the historical division of the department of cultural affairs, the state archaeologist ..., any county conservation board, and any city or agency of a city." 28 The Arkansas, Missouri, North Carolina, and Ohio lists of permissible governmental holders are similarly specific. ${ }^{29}$ Because these lists are specific and do not contain categories that cover tribal governments, tribes are unlikely permissible holders under these states' conservation easement acts.

This brief examination of state conservation easement statutes indicates that where states recognize tribes as governmental entities and acknowledge their right to hold property, tribal conservation easements should be enforceable in state courts. There are, however, several state conservation easement statutes that do not recognize tribes as permissible holders. Thus, if tribes decide to hold conservation easements in those states, they run the risk that the state courts will not uphold the agreements. Few conservation easement disputes reach the courts, but tribes would be appropriately cautious to avoid entering into agreements that do not have the force of state law behind them. However, as with most inquiries into tribal endeavors, state law may not be the right body of law to consider.

\footnotetext{
${ }^{26}$ NEB. REV. ST. §76-2, 11 (2)(a). Some state statutes are inartfully written, and it is not clear whether governmental bodies must have conservation purposes or whether that requirement is only related to nonprofit holders. Florida's law states that conservation easements "may be acquired by any governmental body or agency or by a charitable corporation or trust whose purposes include protecting natural, scenic, or open space values of real property," etc. FLA STAT. CH. 704.06(3). It is not clear whether the governmental body or agency must be one that has conservation purposes or whether that qualification applies only to charitable corporations or trusts. New Hampshire's and Rhode Islands' laws are similar in that respect. It is not clear whether governmental bodies have to have certain conservation-related purposes or whether all governmental bodies are permissible holders. N.H. REV. StAT. ANN. § 477:4; R.I. GEN. LAW. § 34-39-3.

${ }^{27}$ N.MEX.§ 47-12-2(A).

${ }^{28}$ IOWA § 457A.1.

${ }^{29}$ Ark. Code. Ann. § 15-20-402(2)(A); Mo. Rev. Stat. § 67:870; N.C. Gen. Stat. § 121-35(2); Ohio Rev. Code Ann. $\S 5301.69$.
} 


\section{Other Sources of Law}

\section{Tribal Law}

Typically, transactions involving tribes would be governed at least in part by tribal law. Currently, however, no tribes have conservation easement statutes. A tribe could establish such a statute, perhaps following the experiences of the states or looking to the Uniform Conservation Easement Act. Yet the state statutes establish property rules for land within their boundaries. They do not give state governments the ability to create enforceable mechanisms outside their jurisdiction, which is what tribes seek to do where the hold conservation easements. Conservation easements represent an opportunity for governments to influence land use both within and without their jurisdiction. When outside their jurisdiction though, government entities must abide by the rules of the jurisdiction they are in. Thus, tribal conservation easement statutes could govern the use of conservation easements on lands where tribes have jurisdiction, but it is not clear whether such agreements would provide an enforcement mechanism for agreements tribes make off-reservation. ${ }^{31}$ Federal courts have held that a tribe's civil and criminal jurisdictional authority does not extend beyond Indian land, except under specific circumstances. In Montana v. United States, 450 U.S. 544 (1981), the Supreme Court outlined the two exceptions to the default presumption that tribes have no jurisdiction over nonmembers or offreservation. Under the first Montana exception, tribes may "regulate, through taxation, licensing, or other means, the activities of nonmembers who enter consensual relationships with the tribe or its members, through commercial dealing, contracts, leases, or other arrangements." 32 The second Montana exception recognizes a tribe's authority "to exercise civil authority over the conduct of nonIndians on fee lands within its reservation when that conduct threatens or has some direct effect on the political integrity, the economic security, or the health or welfare of the tribe." ${ }^{33}$ Arguably the first Montana exception applies to conservation easements held by tribes. A landowner who donates or sells a conservation easement to a tribe enters into a consensual relationship with the tribe. Conservation easements fall somewhere between a contract and a lease and it appears likely that a federal court should hold that the fist Montana exception applies and tribal law (and therefor tribal jurisdiction) governs; especially where the terms of the conservation easement illuminate the tribal role and refer to tribal statutes or regulations.

However, federal courts have been hesitant to recognize the applicability of the Montana exceptions, and there appears a particular resistance when the regulation involves land held by non-Indians. In Brendale, the Court limited the tribe's ability to zone on-reservation fee lands owned by nonmembers to cover only those lands on the "open" part of the reservation. More recently in Plains Commerce Bank $v$.

\footnotetext{
${ }^{30}$ Although this chapter only discusses the state law implications of state conservation easement statutes, some states may enable tribes to enter into traditional servitudes and allow enforcement of such agreements under traditional property law. This is likely to be easiest where the land in question physically touches tribal land.

${ }^{31}$ Tribal jurisdiction on and off tribal land has had a long and complicated history. In Brendale v. Confederated Tribes and Bands of the Yakima Indian Nation, 492 U.S. 408 (1989), the Supreme Court held that tribes have the ability to regulate land use on tribally held land, but only on some of the fee land within a reservation (the fee land on "closed" parts of a reservation).

${ }^{32}$ Montana v. United States, 450 U.S. 544, 565 (1981).

${ }^{33}$ ld. at 565-66.
} 
Long Family Land \& Cattle Co., 544 U.S. 316 (2008), the Court held that sale of on-reservation fee lands was not subject to tribal jurisdiction. In Plains Commerce Bank, Justice Roberts (writing for the majority) emphasized that a tribe may have the power to regulate certain activities on such lands, but it does not have the ability to regulate sales of such land. ${ }^{34}$ The restrictions in conservation easements look more like zoning than sales, but the nature of a conservation easement means that the restrictions run with the land - that is new landowners will be bound by the agreement entered into by the previous landowner. Although the decision in Plains Commerce Bank describes the dispute as a sale of land from a non-Indian (the Bank) to other non-Indians, the facts of the case indicate that the essence of the dispute centered on an Indian landowner its dealings with the Bank. Thus, while conservation easements appear to fall comfortably within the first Montana exception, the uncertainty in this area of law makes enforceability of a tribal conservation easement statute questionable. ${ }^{35}$

\section{Federal Law}

States generally have authority over tribes and tribal members for activities off reservation. ${ }^{36}$ But Congress can legislate otherwise, preempting the application of state law with respect to matters involving the unique relationship between tribes and the federal government. ${ }^{37}$ Further, many offreservation activities by tribes are already grounded in federal law. Federal law might, therefore, provide avenues for enforcement of tribal conservation easements.

Case law seems to indicate that conservation easements established pursuant to a federal plan need not adhere to state conservation easement statutes. For example, in North Dakota, conservation easements may not be perpetual. ${ }^{38}$ Yet, the Eighth Circuit upheld perpetual conservation easements held by the federal government. ${ }^{39}$ The court held that where state law is "aberrant or hostile to federal property rights," it is not controlling. ${ }^{40}$ The Eighth Circuit found it unnecessary to explore the state law questions because if they were at all hostile to the federal property rights in the conservation easement, they would not have precluded the conveyance of the disputed property right. The court stated:

We fully recognize that laws of real property are usually governed by the particular states; yet the reasonable property right conveyed to the United States in this case effectuates an important national concern, the acquisition of necessary land for waterfowl production areas, and should not be defeated by any possible North Dakota law barring the conveyance of this property right. To hold otherwise would be to permit the possibility that states could rely on local property laws to defeat the acquisition of reasonable rights to their citizens' property ... and to destroy a national program of acquiring property to aide in the breeding of migratory birds. We, therefore, specifically hold that the

\footnotetext{
${ }^{34}$ Plains Commerce Bank, 544 U.S. at 334.

${ }^{35}$ Additionally, landowners may be hesitant to agree to conservation easements that subject them (and future landowners) to tribal jurisdiction. Landowners may insist that conservation easement be enforceable in state court or through arbitration.

${ }^{36}$ Mescalero Apache Tribe v. Jones, 411 U.S. 145 (1973).

${ }^{37}$ See, e.g., The Indian Child Welfare Act of 1978, 25 U.S.C. §§ 1901-63.

${ }^{38}$ N. D.CENT. CODE $§$ 47-05-02.1(2) (2011).

39 United States v. Albrecht, 496 F.2d 906 (8th Cir. 1974).

${ }^{40} / d$. at 911.
} 
property right conveyed to the United States in this case, whether or not deemed a valid easement or other property right under North Dakota law, was a valid conveyance under federal law.... ${ }^{41}$

The Supreme Court further supported the idea that federal conservation easements do not need to adhere to state law. ${ }^{42}$ In North Dakota v. United States, the Court held that North Dakota could not restrict the federal government's ability to acquire conservation easements and prohibited the North Dakota legislature from placing any restrictions on acquisition that directly conflict with federal goals.

This indicates that if the federal government established a program to fund and support tribes' acquisition and administration of conservation easements, there may be no need to turn to state conservation easement statutes for validity. Tribes may seek such an arrangement even in states that allow tribes to hold conservation easements. Tribes may prefer to act under a federal scheme and bring their case in federal court if they are concerned about a hostile state court. ${ }^{43}$

Another way to reach a similar result is to have the conservation easement held by the federal government. When a tribe decides to use conservation easements to achieve its conservation goals, it should consider whether it wants to hold the property interest or it wants the federal government (via the Bureau of Indian Affairs or BIA) to hold the property interest on its behalf. ${ }^{44}$ Tribes can hold interests in land without the involvement of the BIA, but the BIA is the designated federal trustee of tribal property. Where the federal government is the holder, not only is there a stronger argument that the holder need not comply with the terms of a state conservation easement statute for validity but also the government may be invoke the Property Clause to enforce the agreement. The Property Clause of the Constitution enables the federal government to make all needful rules regarding federal land. ${ }^{45}$ Arguably, this includes rules regarding nonpossessory or partial interests as well. ${ }^{46}$

\section{Unique Implications of Tribal Ownership}

Where a tribe holds a conservation easement, there are unique issues of enforcement and accountability. While conservation easements give the holder a right of enforcement, there are also situations where a landowner burdened by a conservation easement would wish to enforce the agreement against the holder. This could happen where the conservation easement includes affirmative obligations on the part of the conservation easement holder (such as trail maintenance or invasive species removal). Most state statutes explicitly recognize the right of landowners to bring actions

\footnotetext{
${ }^{41} / d$.

${ }^{42}$ North Dakota v. United States, 460 U.S. 300 (1983)

${ }^{43}$ Of course, landowners may prefer state law (and enforcement through state courts).

${ }^{44}$ The Secretary of Interior may acquire interests in off-reservation lands--including water and surface rights - "for the purpose of providing land for Indians." Indian Reorganization Act of 1934, 25 U.S.C. § 465 (2006.) The process for acquiring such property interests can be onerous and time consuming. 25 C.F.R. part 151 (2010).

${ }^{45}$ U.S. CONST. art. IV, $\S 2, \mathrm{cl} .3$.

${ }^{46}$ Indeed, the regulations regarding land acquisition for Indians recognizes the ability of the federal government to acquire partial property interests. 25 C.F.R. $\S 151.7$.
} 
against conservation easement holders. ${ }^{47}$. Where such cases arise, however, the landowner may have a tricky road to navigate in determining where (in which court) to bring the case and establishing that the tribe has waived it sovereign immunity.

The venue of the case will turn on the facts of the situation, but the options are tribal, state, or federal court. Landowners may be resistant to entering into a conservation easement if it appears that the only judicial recourse is tribal court. Non-tribal members (and the federal judiciary) have often expressed hesitancy about tribal courts, and a landowner encumbered by a conservation easement may worry that a tribal adjudication of her claim will be unfair. For similar reasons, a tribe may balk at having state courts preside over conservation easement disputes. Conservation easements that will be (or may become $)^{48}$ held by tribes should be clear about venue for any disputes.

The more complicated issue is whether the tribe can be sued. As with other sovereign governments, tribes can only be sued where they have so consented. The doctrine of sovereign immunity protects tribes from lawsuits. A landowner bringing suit against the tribe must show that the tribe has waived it sovereign immunity..$^{49}$ Waivers of tribal immunity must be clear. ${ }^{50}$ Without a tribal statute regarding conservation easements, the terms of the conservation easement itself must form the basis for waiver.

Potentially more common than landowner suits for enforcement are actions challenging a holder's lack of enforcement. Such cases would arise where a conservation easement holder fails to enforce a conservation easement (whether by choice or inadvertence) or the holder has agreed to terminate or modify a conservation easement in circumstances that others find objectionable. For example, in the Myrtle Grove Controversy, the National Trust agreed to amend a conservation easement in ways that the grantor's descendants (not the underlying landowners), neighbors, environmental organizations, and attorney general felt went against the purposes of the conservation easement and violated the charitable trust created by the conservation easement. ${ }^{51}$ In a more recent case, the IRS penalized a

\footnotetext{
${ }^{47}$ See, e.g., UCEA §3(a)(1). The notes following this section explain, "Owners of interests in real property burdened by easements might wish to sue in cases where the easements also impose duties upon holders and these duties are breached by the holders."

${ }^{48}$ There is an added complication that has yet to arise in practice. Theoretically, a landowner could negotiate a conservation easement with a government agency or nonprofit organization that then transfers the conservation easement to a tribe. If the parties did not contemplate the possibility of a tribal holder at the outset of the agreement, the conservation easement deed is unlikely to address issues of venue and sovereign immunity. Where a state government entity holds a conservation easement and waived its sovereign immunity regarding the conservation easement, would a tribe's acceptance of transfer constitute a waiver of sovereign immunity? This is a complicated question that may never arise in practice, but with perpetual agreements it is hard to predict the future.

${ }^{49}$ See, e.g., Kiowa Tribe v. Mfg. Techs., Inc., 523 U.S. 751, 754 (1998)

${ }^{50} \mathrm{~A}$ tribe can waive its sovereign immunity, C \& L Enters., Inc. v. Citizen Band of Potawatomi Indian Tribe, 532 U.S. 411, 418 (2001), of Congress can waive a tribe's immunity, Santa Clara Pueblo v. Martinez, 436 U.S. 49, 58-69 (1978). In either situation, the waiver must be clear.

${ }^{51}$ Nancy A. McLaughlin, Amending Perpetual Conservation Easements: A Case Study of the Myrtle Grove Controversy, 40 U. RICH. L. REV. 1031 (2005-2006).
} 
charitable organization that was not enforcing its conservation easement by stripping it of its charitable tax-exempt status. ${ }^{52}$

While not overwhelming, there are increasing numbers of cases where the actions of conservation easement holders are being challenged. Where the holders are charitable organizations, there are possible repercussions for failing to enforce conservation easements. The organizations may lose their 501(c)(3) status, have to pay fines, or find themselves at the wrong end of an expensive law suit (as occurred with the National Trust). ${ }^{53}$ Where the conservation easement holder is a governmental entity, there are other methods of compelling enforcement. While the exact mechanisms vary by state, there are usually avenues of enforcement through state and federal administrative procedure acts. ${ }^{54}$

Where the holder of the conservation easement is a tribe, the responses to lack of enforcement are less clear. This is especially true if there is no clear waiver of sovereign immunity. Public outcry and bad press may be persuasive enough, especially where a tribe is eager to build or maintain community relationships and goodwill. In some states, the attorney general (or possibly another entity) may be able to enforce directly against a landowner, but she may be hesitant to do so if it could cause political problems.

At the end of the day, this lack of certainty regarding accountability and enforcement may lead landowners to be cautious about entering into conservation easements with tribes. If a landowner is seeking a tax deduction for donation of a conservation easement, the choice of a tribe as the conservation easement holder could raise questions about long-term viability with the IRS. Despite these abstract concerns, however, there have not been any actual problems with tribal holders of conservation easements. In fact, as with the Hydes and their agreement with the Klamath Tribes, landowners may feel tribes are the most likely entities to comport with their long-term visions of the land.

\section{WHY: The Choice to Hold Conservation Easements}

Beyond the complicated discussion of state laws and avenues for enforcing tribal conservation easements, lies another important inquiry. Why do tribes choose to hold conservation easements? This

\footnotetext{
52 I.R.S. Priv. Ltr. Rul. 201109030 (March 4, 2011)

${ }^{53}$ In the Myrtle Grove case, the National Trust originally consented to conservation easement amendments that would have conflicted with the conservation easement (and arguably the charitable trust it created). After public protests, the National Trust withdrew its consent for the amendment and was then sued by the landowner for breach of trust. The National Trust settled the case but for a substantial amount and only after extensive judicial proceedings. McLaughlin, supra note 52, at 1062 .

${ }^{54}$ In such cases, persons would sue the agency for failing to enforce the agreement. This would be a complicated arrangement requiring state statutes enabling the suit and a showing of statutory and constitutional standing. It is an inefficient route of enforcing a conservation easement. It is a suit compelling someone else to enforce a law (as opposed to a citizen-suit-style provision that would enable someone with standing to bring suit directly against the landowner, requiring landowner compliance with the terms of the conservation easement. Jessica Owley Lippmann, Exacted Conservation Easements: The Hard Case of Endangered Species Protection, 19 J. ENVTL. L. \& LITIG. 293, 345-52 (2004).
} 
section briefly discusses why tribes might consider holding conservation easements on non-tribal lands. ${ }^{55}$

Most conservation easement holders use the tool because they are concerned about environmental amenities and want to protect land. The question here is not why organizations and governments care about land conservation, but why they choose to use the conservation easement tool among the array of tools available. Making that assessment in the present context requires considering what tools are available to tribes seeking to conserve land outside their jurisdiction.

Where a tribe chooses to hold conservation easements instead of purchasing fee simple title to the land, cost may be a strong motivator. Usually, purchasing a conservation easement is cheaper than buying fee simple title. And conservation easement holders do not have to pay property taxes. Holding a conservation easement may also be preferable to fee simple ownership because the land management duties remain with the underlying landowner. There is no need for tribal employees to maintain the land, keep out trespassers, or act as landlords. This is particularly salient for conservation easements over working lands, like ranches, forests, and agricultural land. A tribal government may not want to engage in agriculture or forestry. Leaving the landowner in place, while the tribe holds only the development rights, alleviates the need to find tenants and manage leases. These cost factors may be strong motivators for tribes who have less robust tribal governments and lower enrollments. Many tribes-like the Klamath-however, seek to gain fee simple title to land. The choice of a conservation easement may simply be tied to a landowner's unwillingness to sell.

Many argue that conservation easements are more likely to persist than fee simple land ownership. A parcel held in fee can always be sold or conveyed. At least in theory, a conservation easement can be perpetual. A tribe can transfer a conservation easement to a qualified holder if it no longer wants the burden of being a holder, but the restriction on the land remains in place. For this reason, conservation easements are appealing to tribal government officials who worry that subsequent office holders will not share their conservation goals. Conservation easements enable current tribal leaders to shape the local landscape in a way not possible through fee simple purchase.

Owning conservation easements instead of fee title may also be more politically appealing. Community members might balk at having large parcels of land under tribal ownership. Perhaps there are concerns about the tribal jurisdiction. Neighboring property owners may be concerned that tribal ownership will mean casino development. Building relationships through conservation easement programs may help demonstrate a tribe's interest in land conservation.

\footnotetext{
${ }^{55}$ Determining why conservation easements holders choose to hold conservation easements necessarily involves broad generalizations and hypotheses regarding motivations that we cannot actually discern without in-depth examinations and interviews with each of the tribes holding conservation easements. While such a project is underway and will enrich understanding of conservation easement use, it is beyond the scope of this chapter. Instead, this chapter presents theories of why tribes hold conservation easements based on the benefits conservation easements can provide to governments, public statements by tribes and others, and a general examination of the tool's benefits.
} 
Where tribes hold conservation easements, they have a unique ability to extend their goals of protecting resources beyond their jurisdiction. In cases like the Yainix Ranch, tribes can secure conservation easements over land that they had traditionally held but lost through treaties and termination. Tribes may also seek to use conservation easements to protect off-reservation lands that serve as subsistence resources. This is a way to assert interest in tribal lands not officially recognized as such by state and federal governments.

Protection of land outside of reservations also promotes the ecological health of reservation lands. As Mary Wood has noted, tribes are often searching for ways to protect their natural resources and "extend their environmental prerogatives" beyond reservation boundaries. ${ }^{56}$ Preventing development and unsustainable practices on neighboring land can protect environmental benefits on tribal land. Tribes and other governments often fight battles over water quality with their upstream neighbors. Obtaining conservation easements over such land may ensure water quality protection beyond the current methods offered by the Clean Water Act. ${ }^{57}$

\section{Holding Conservation Easements and Traditional Notions of Tribal Property Law}

Many scholars studying conservation easements and activists working in the field are unaware of the extent tribes use conservation easements. ${ }^{58}$ Many concerns regarding conservation easements relate to their use as a conservation tool. Essentially, it is questionable whether static, perpetual, piecemeal agreements make sense for long-term land protection. ${ }^{59}$ Some may be particularly surprised by tribal use of the tool because conservation easements embrace and reify western libertarian notions of property.

The use of conservation easements represents an unwelcome shift in property law that continues a move toward valuing individual real property rights over social good. Conservation easements reinforce the bundle of sticks metaphor of property implying that all property rights rest with individual landowners who should be compensated for any detraction from those rights or limitations on their actions. This ignores the fundamental role of property as a social construct to meet evolving needs of the community.

Conservation easements reinforce a present libertarian view of property where the individual landowner has the right to determine what occurs on the land. ${ }^{60} \mathrm{~A}$ person has rights as a landowner, but

\footnotetext{
${ }^{56}$ Mary Christina Wood \& Zachary Welcker, Tribes as Trustees Again (Part I): The Emerging Tribal Role in the Conservation Trust Movement, 32 HARV. ENVTL. L. ReV. 373, 393 (2008).

57 In a related example, New York City uses conservation easements extensively in the Catskills to protect the New York City watershed. Using conservation easements to protect land and restrict agriculture in riparian areas is a more effective and efficient way to ensure high water quality in the region than outright ownership.

${ }^{58}$ But see, Wood \& Welcker, supra note 57 and Middleton, supra note *.

${ }^{59}$ See, e.g., Jessica Owley, Changing Property in a Changing World: A Call for the End of Perpetual Conservation Easements, 30 STAN. ENVTL L. J. 121 (2011) (also raising concerns regarding accountability and justice).

${ }^{60}$ There are some in the property rights movement that disagree with this view of conservation easements, arguing instead that conservation easements erode private property rights because they give nonlandowners
} 
those rights are necessarily tempered by societal rights. Private property developed because it meets societal needs. Where property ceases to benefit society, it ceases to serve a viable function and does not merit public enforcement.

Thus, private property exists to further social goals and should be tempered by societal needs. Solidifying the power of individual landowners creates an anticommunitarian view of property and may make needed regulation (and other land-protection strategies) even more difficult to achieve. The use of conservation easements and other mechanisms where we pay landowners to refrain from harmful activities overlooks the fact that landowners can be prevented from engaging in such activities by common law nuisance concepts or land use and environmental regulation. We have instead created a market for something that someone should not necessarily be paid for. With conservation easements, we perpetuate the myth that the landowner is the king or queen of a realm where others' rights are always subservient to theirs. We strengthen the resistance to government regulation and suggest that landowners have no responsibility regarding the land.

These significant objections to the use and proliferation of conservation easements served as the background for this investigation into how tribes are becoming involved with conservation easements. While concerns with the tool overall remain, this project reveals not only the attraction of conservation easements for tribes but also how conservation easements may present a vestige of tribal notions of land conservation and intergenerational equity.

Traditional landholdings were extraordinarily complex, recognizing the shifting rights of individuals and groups in the same parcel of land. The idea of a fee simple landowner was not often a format for tribal property interests. The idea that one person can assert control over a piece of land, sometimes in defiance of group interests or wishes, does not comport with most traditional tribal notions of land use. ${ }^{61}$ This indicates why conservation easements may be in conflict with traditional tribal notions of property. Conservation easements put the individual landowner center stage as the decision maker. The landowner receives compensation for changes to the land. The landowner has the power to bind the rights of future generations regarding the land. Winona LaDuke objects that this western view of natural

rights perpetual rights in the land. See, e.g., Carol W. LaGrasse, Land Trusts Threaten Private Property 5 PosITIONS ON PROP. (2000), unpaginated excerpts available at PROPERTY RIGHTS FOUNDATION OF AMERICA, http://prfamerica.org/positions/LandTrustsThreatenPP.html; J.B. LOVE, CONSERVATION EASEMENTS FROM THE LANDOWNER'S PERSPECTIVE-BOON OR BOONDOGGLE (undated), available from the Davis Mountain Trans-Pecos Heritage Assoc. and summary available at http://dmtpha.org/easement.htm (last visited June 22, 2011). Others argue that conservation easements represent an unwanted form of government ownership and regulation. Dana Joel Gattuso, Conservation Easements: The Good, the Bad, and the Ugly, NATIONAL Policy ANALYSIS \#569 (May 2008), available at http://www.nationalcenter.org/NPA569.html. It does not appear that these organizations oppose nonpossessory rights (such as easements and real covenants), but largely object to conservation easements because of the government involvement and funding of the programs.

${ }^{61}$ That is not to say that tribes did not recognize individual ownership interests or that one mode of thinking about property describes all tribal experiences or histories. For example, early laws of the Cherokee Nation recognize the right of individual Cherokees to own land. Stacey L. Leeds, The Burning of Blackacre: A Step Toward Reclaiming Tribal Property Law, 10 KAN. J.L. \& PUB. PoL'Y 491, 493 (2000). Individual ownership of land, however, is not necessarily synonymous with Blackstonian fee simple ownership, and tribes mores and laws were often more restrictive on use and dispersal of land than Anglo property laws. 
resources as inanimate things that man can commodity and manipulate is inherently at odds with the traditional Indian view of land. ${ }^{62}$

There are some aspects of conservation easements, however, that do not seem to be so directly counter to tribal property notions. For example, conservation easements acknowledge that multiple people or groups can hold different interests in the same parcel. The fee landowner may have the right to occupy the land, but someone else may have the right limit the development of the land. Mary Wood argues that conservation easements are more akin to tribal property notions than it may first appear because both support beneficial uses of natural resources and reject exclusive use of land. ${ }^{63}$

While conservation easements solidify power of individual landowners, they simultaneously acknowledge the ability of multiple parties to hold rights in the same parcel of land. This aspect of conservation easements may coincide with earlier expressions of tribal rights. Treaty rights, for example, often recognize that tribes have interests related to land that they do not occupy or that are not recognized as tribal land by the federal government. Where treaties recognize tribal rights to hunt, gather, or fish on land that they do not hold, those rights look very similar to easements. ${ }^{64}$

Conservation easements generally appear to reinforce a misguided notion that property law gives individual landowners the ability to put the land to any use they deem beneficial without consultation with or limitation by society. Yet, the availability of conservation easements may present an opportunity for tribes to use western property law concepts in a beneficial way. With conservation easements, tribes can exert influence and even a type of property interest over lands that they identify as belonging to the tribe even if the federal or state governments do not.

Tribal notions of property and natural resources recognized the need to protect the land for future generations. Conservation easements seek to do that but with a twist. Protecting land for future generations is not necessarily the same as preventing future generations from using the land in ways they so choose.

There is a bit of a conservation conundrum before us. Conservation easements may create cumbersome structures for future generations, but this cumbersome and potentially unjust structure may be necessary to prevent present development and degradation pressures. Inequitably restricting future generations appears a price we are willing to pay. Although conservation easements restrict future generations, the real aim appears to be limitations on current use. Embodied in the narrative of conservation easement use is a belief that future generations are going to be better at protecting the land than current generations are because they will see the need for land protection more acutely than do current generations. Thus, what now appear as cumbersome restrictions may not seem so onerous

\footnotetext{
${ }^{62}$ WINONA LADUKE, VoICES FROM WHITE EARTH 35-37 (1993)

${ }^{63}$ Wood \& Welcker, supra note 56, at 379.

${ }^{64}$ In particular, they are akin to a category of easements called profits (or profit à prendre). Such easements recognize an individual's or landowner's right to take natural resources such as forest products or wildlife from the burdened land. See also, id. at 387 (describing the Supreme Court's treatment of the Stevens Treaties in the Pacific Northwest, which the Court described as reserving "easements").
} 
to them. Preventing development and diminishing degradation may provide more future options even if it entails encumbering the land.

In the end, conservation easements may provide tribes with a novel way of protecting land in a country where tribal sovereignty is continually diminishing and tribal land bases have a tendency to shrink rather than expand. From a programmatic standpoint, details regarding jurisdiction and enforceability may hamper the immediate growth in use of the tool. The strength and sensibility of conservation easements will likely vary with the restrictions they entail. Some conservation easements may make more sense ecologically and politically than others. For example, conservation easements protecting open space and watershed health fit the tool better than conservation easements seeking to protect mobile resources (such as elk) or ecosystems likely to change with global warming. Tribes can take advantage of the experience of those who have gone before them in this area, examining the concerns and challenges that other governmental entities and land trusts have faced. In particular, tribes should be cautious regarding how they use conservation easements-ensuring that the tool lines up with their goals. 